\title{
Characteristic Study of Film Thickness on Countercurrent of Water-Air Flow in Hot-Leg Simulator of L/D $=25$ by using Parallel-Wire Methods
}

\author{
Radhi Ariawan ${ }^{\mathrm{a}}$, Deendarlianto ${ }^{\mathrm{b}}$, Indarto ${ }^{\mathrm{b}}$, Apip Badarudin \\ ${ }^{a}$ Magister Program of Mechanical Engineering, Gadjah Mada University \\ b,c Department of Mechanical and Industrial Engineering, Gadjah Mada University \\ ${ }^{d}$ Doctoral Program of Mechanical Engineering, Gadjah Mada University \\ e-mail: radhi.4riawan@gmail.com
}

\begin{abstract}
In water-air counter current flow, relative movement between water and air occurred. The results of this movement interfacial instability occurred in the flow, causing the liquid film moves up and down. In this study, film thickness characteristics of water-air counter current flow in $L / D=25$ hot-leg simulator are identified. Film thickness measurement was carried out using parallel-wire sensor consists of parallel wires installed through the pipe's cross sectional area with spacing of $5 \mathrm{~mm}$. sensor has wire diameter of 0,51 $\mathrm{mm}$ made from copper coated in silver. This experimental study was carried out with water superficial velocity (JL) variation of $J L=0,003 \mathrm{~m} / \mathrm{s}, J L=0,032 \mathrm{~m} / \mathrm{s}$, and $J L=0,065 \mathrm{~m} / \mathrm{s}$. From the film thickness measurement, film thickness characteristics of water-air counter current flow are identified based on the flow pattern and the position of onset of flooding. $J \mathrm{~L}$ variation affects the occurring time of flow pattern change, hydraulic jump, and onset of flooding. Hydraulic jump and onset of flooding position occurred further from the bend as the $\mathrm{JL}$ increased. Onset of flooding occurrence time is faster as the $\mathrm{JL}$ bigger.
\end{abstract}

Keywords: film thickness; parallel-wire; onset of flooding; counter current flow

\section{INTRODUCTION}

Two phases current is categorized as multiphase flow which involve two different phases flow. Characteristic of two phases flow may incur losses in form of sudden decrease of pressure and change drastically. Therefore, many studies on development of two phase flows and one of them are in nuclear reactor type PWR (Pressurized Water Reactor). In PWR reactor, terrace temperature is kept stable so that a phase change doesn't occur by keeping water pressure always high. One of the accidents in PWR nuclear reactor is LOCA (Los of Coolant Accident). In LOCA scenario, primary piping leakage lead to pressure drop and evaporation occur. The steam generated then flows into steam generator thru hot-leg pipe. The success of cooling of reactor core based on this scenario is much depends on behavior of counter flow between steam and condensate which flow to hot-leg pipe. The flow is only stable on certain water and air mass flow. When air flow rate is increased gradually until maximum in which water mass flow rate flows into reactor tube has equal pressure with mass flow rate of inlet, then this point is defined as start of flooding or onset of flooding [1]. One of criteria of occurrence of flooding is big wave generation when film is thick enough to generate wave with high amplitude in interface between water and air [2].

Parallel-wire sensor in investigation of film thickness measurement has been used. It assumed that electric conductivity of water between two wires is equal to the length of wetted so that the sensor can be used to determine thickness of liquid in separated flow 
(stratified flow and annular flow). Senor also been used to detect slug liquid in intermittent flow. When slug pass the sensor then output signal will show different value with stratified flow [3], [4]. In condition of electric current is kept constant, electrical resistance will grow bigger for thinner film [5].

\section{Methodology}

The research was started by pumping water into supply tank. In this condition, valve connected to supply tank outlet was closed to prevent water flow out from tank. Then water from supply tank was flown into flowmeter to measure superficial velocity of water so that it can be controlled according to the need during experiment. From flow meter, water was flown into hot-leg pipe. Water flown into upper tank, inclined pipe, elbow, horizontal pipe, and finally to lower tank as shown in Figure 2.1. At the same time, air was injected to horizontal pipe in counter flow with water by using air compressor and was controlled for its superficial velocity by using flow meter. Water superficial velocity (JL) was kept constant and superficial velocity of air (JG) was increased gradually for JG = $0.164 \mathrm{~m} / \mathrm{s}$ every 15 seconds. There were 3 (three) variations of used water superficial velocity (JL), i.e. $\mathrm{JL}=0.003 \mathrm{~m} / \mathrm{s}, \mathrm{JL}=0.032 \mathrm{~m} / \mathrm{s}$, and $\mathrm{JL}=0.065 \mathrm{~m} / \mathrm{s}$.

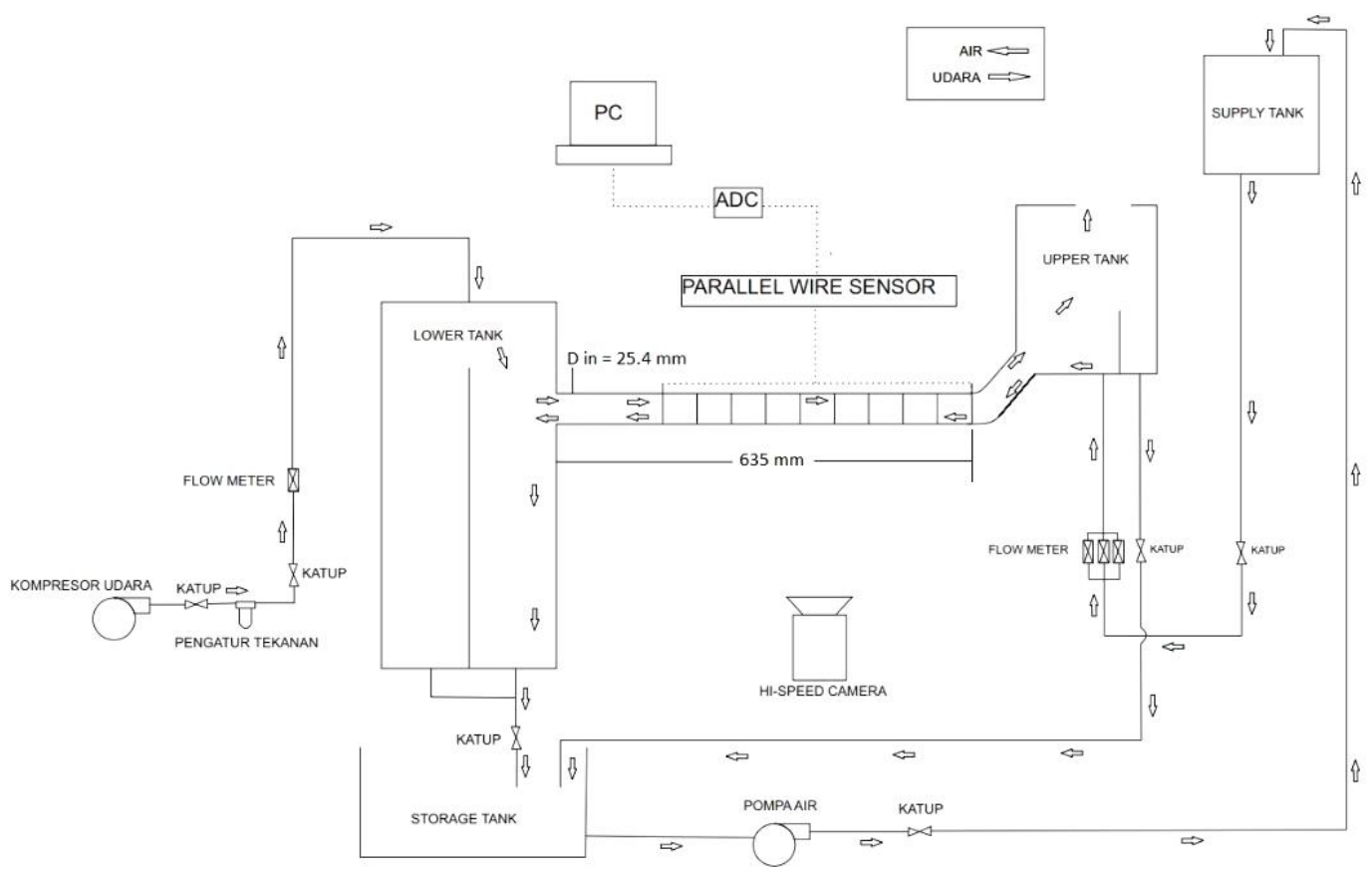

Figure 2.1 Research set-up

Value of JL and JG was obtained from the conversion of water and air mass flow by using the equation:

$$
\begin{aligned}
& J_{L}=\frac{4 Q_{L}}{\pi D^{2}} \\
& I_{G}=\frac{4 Q_{G}}{\pi D^{2}}
\end{aligned}
$$

Position of each sensors was shown in Figure 2.2. Block diagram of measurement of film layer thickness consisted of sensor, amplifier, Data Acquisition System (DAQ), and computer as shown in Figure 2.3. Parallel-wire sensor consisted of two wires which positioned parallel each other on the pipe cross section of $25.4 \mathrm{~mm}$ in diameter. Sensor 
wire has $0.51 \mathrm{~mm}$ in diameter and manufactured from copper wire coated by silver. The distance between two wires was $5 \mathrm{~mm}$ as shown in Figure 2.4.

The block diagram of research and sensors were arranged according to research conducted by Badarudin [6]. Signal conditioner in form of Wheatstone bridge was supplied by direct current of 12 Volt. Wheatstone bridge output was direct current in range of 0-10 Volt. The output then was fed into DAQ system.

\section{SENSOR PARALLEL-WIRE}

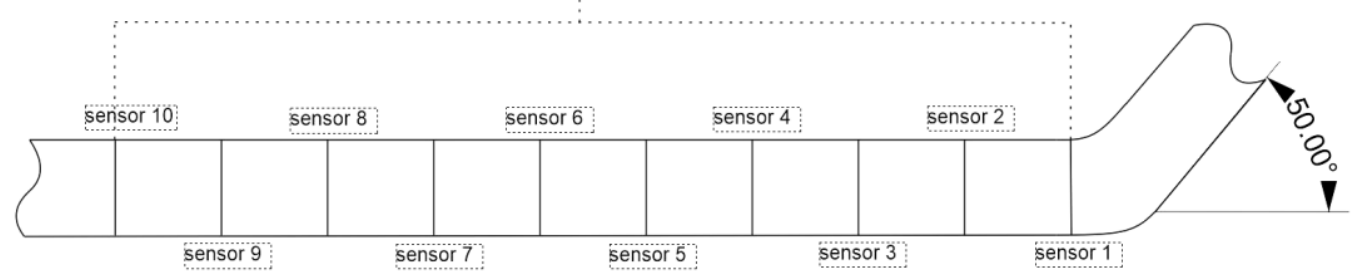

Figure 2.2 Position of each sensors in hot-leg simulator

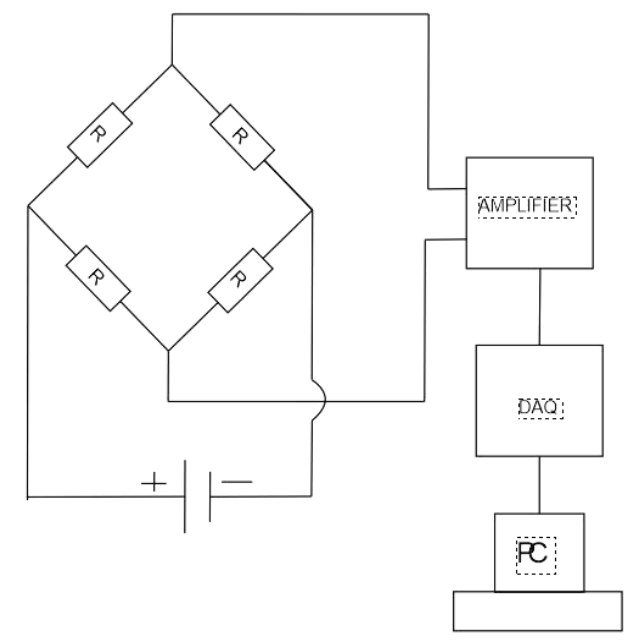

Figure 2.3 Block diagram of measurement of film layer thickness

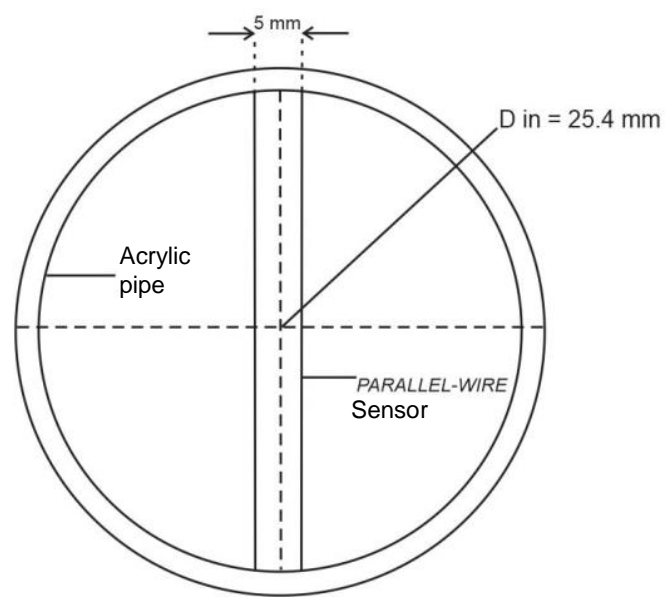

Figure 2.4 Parallel-wire sensor 
Calibration of measurement of film layer thickness using parallel-wire was conducted by referring to previous experiment [6]. Wire sensor installed in pipe was submerged gradually until all wire was wetted by water and water thickness can be determined exactly. Then, voltage of output of wire sensor was read for every thickness of water layer, tabled and depicted for calibration curve. The results of film layer thickness were presented in normalization of graphic response of film thickness to time and changes of superficial velocity of air (JG).

\section{ResUlts AND Discussion}

Basic characteristic of counter current flow is depending on the magnitude of air and water flow rate. Generally, the magnitude of the flow rate will form different type of flow pattern, such as stratified flow, wavy flow, and slug flow [7]. In fixed value of JL condition, the increase of JG makes the friction between interface of water and air increase. As result, instability in the interface of flow will occurs and generate liquid layer which move up and down [1].

Presented response graph shows the position when phenomenon of flow pattern and onset of flooding occur. In this research, the behavior of each parallel-wire sensors show changes of flow pattern which occurs in each superficial velocity of water (JL). Onset of flooding position was detected near elbow for low value of JL. Contrary, onset of flooding position was away from elbow in bigger JL. This pattern was in accordance with research of Deendarlianto [1].

\subsection{The Results of Measurement of Film Thickness for $\mathrm{JL}=0.003 \mathrm{~m} / \mathrm{s}$}

Figure 3.1 show the normalization response of film thickness for sensor 1 , sensor 2 , and sensor 8 for $\mathrm{JL}=0.003 \mathrm{~m} / \mathrm{s}$ to the change of JG. Along with increase of superficial velocity of air, then wave will be generated with amplitude equals to the thickness of liquid film. Thickness of film on senor 1 and 2 has shallow trend until JG $=1.5 \mathrm{~m} / \mathrm{s}$ and increase when $J G>1.5 \mathrm{~m} / \mathrm{s}$. From the reading of sensor 8 , it also show shallow trend to the end. This proved that changes in flow pattern significantly was detected by sensor 1 and 2 which located near elbow.

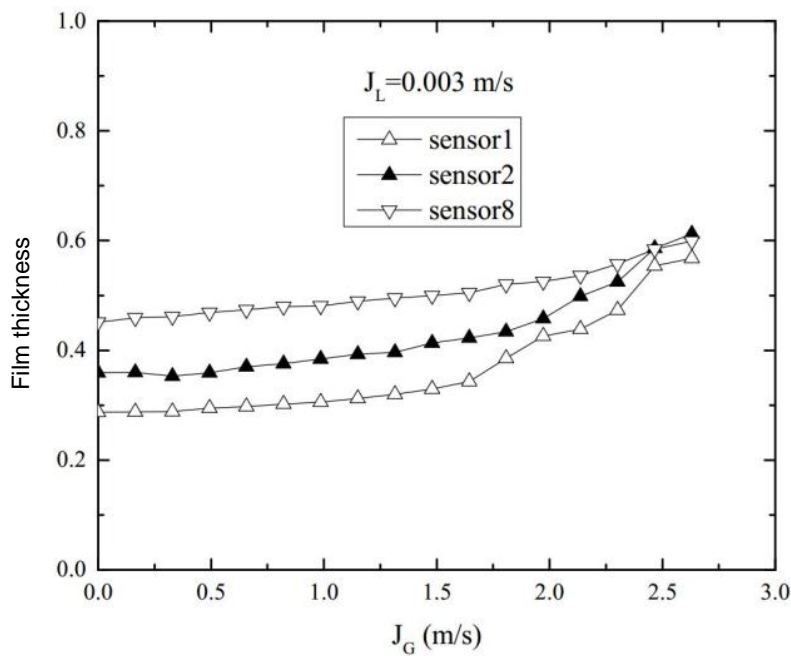

Figure 3.1 Normalization response of film thickness to the changes of JG for $J L=0.003 \mathrm{~m} / \mathrm{s}$

Figure 3.2 show normalization response of film thickness to time for sensor 1, sensor 2 , and sensor 3 on the condition of $\mathrm{JL}=0.003 \mathrm{~m} / \mathrm{s}$. From the measurement of film thickness, there were 3 observed regions. Region I, of range 0-225 second which marked by flat increased of film layer and gradually increased. This show stratified flow. Increase of film thickness was caused by gradual increasing of JG on condition of fixed JL [8]. In 
region $\mathrm{II}$, the large Wavy $(\mathrm{WL})$ flow was generated when $\mathrm{JG}=2.46 \mathrm{~m} / \mathrm{s}$. $\mathrm{LW}$ flow was detected until at the moment before flooding in time range of 15 seconds. The increase of layer thickness was easily observed in sensor 1 and sensor 2 . Meanwhile, region III show the position of onset of flooding (OOF) occurrence which marked by significant increase of film thickness on seconds of $240^{\text {th }}$. The phenomenon was detected by sensor 1 and sensor 2.

In sensor 8, the changes of film thickness was significant and flooding phenomenon was not observed. This show that in low JL, i.e. $\mathrm{JL}=0.003 \mathrm{~m} / \mathrm{s}$, onset of flooding was occurred near elbow.

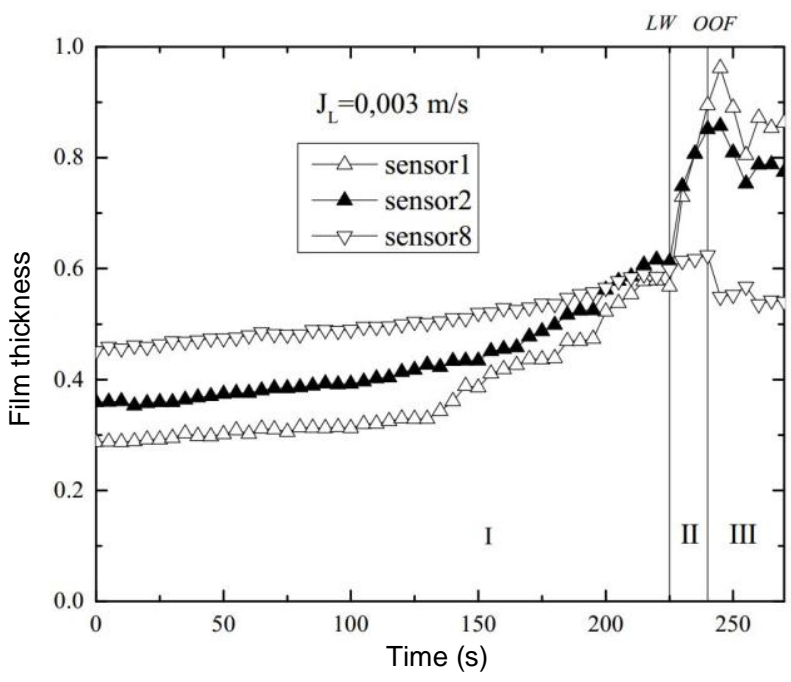

Figure 3.2 Normalization response of film thickness to time for $\mathrm{JL}=0.003 \mathrm{~m} / \mathrm{s}$

\subsection{Measurement of Film Thickness for $\mathrm{JL}=0.032 \mathrm{~m} / \mathrm{s}$}

The results of film thickness measurement for $\mathrm{JL}=0.032 \mathrm{~m} / \mathrm{s}$, show different trend than previous measurement. In Figure 3.3, the sudden change of film thickness was observed by sensor 1 , sensor 2 , and sensor 7 . There was significant increase of film thickness for JG $=1.64 \mathrm{~m} / \mathrm{s}$ as detected by sensor 1 and sensor 4 . Differs from previous measurement, the increase of film thickness was occurred more rapid. The phenomenon of sudden film thickness increase shows the occurrence of onset flooding. When JG increase, then decreasing of film thickness was detected after onset of flooding. The decrease of film thickness was detected by sensor 7, in which JL was fixed and increase of JG until over of the flooding peed generated occurrence of film flow which up-down and finally goes to zero [1].

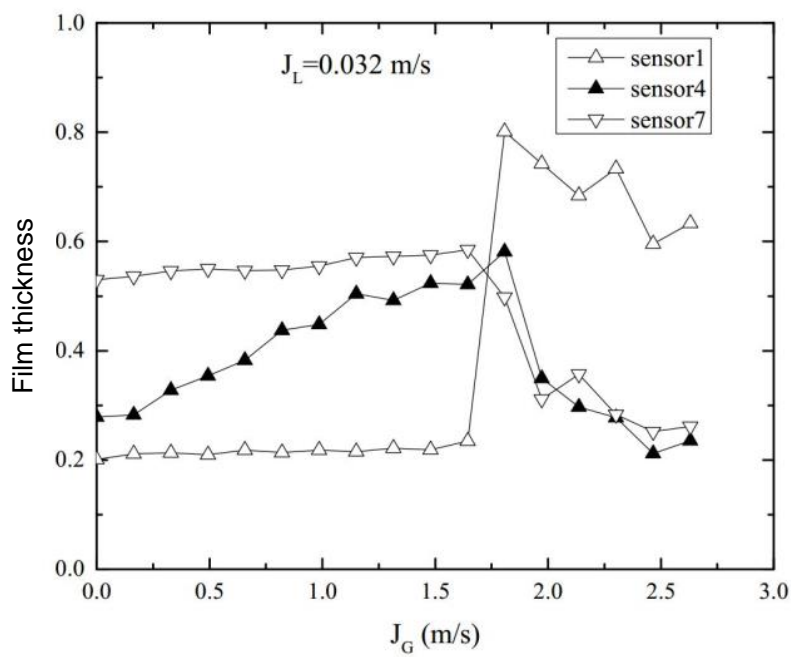

Figure 3.3 Normalization response of film thickness for change of $J_{G}$ for $J_{L}=0.032 \mathrm{~m} / \mathrm{s}$. 
Based on the results of measurement of normalization response of film thickness for $\mathrm{JL}=0.032 \mathrm{~m} / \mathrm{s}$, there were two observed regions. Region I, stratified flow pattern was observed which marked by bold graph of film which has flat trend as shown in Figure 3.4. Sensor 4 in Figure 3.4 shows the occurrence of increasing of film thickness as JG increase. The phenomenon show generation of hydraulic jump which was detected by sensor 4. As JG increased, hydraulic jump was shifted toward elbow. Large Wavy (LW) flow occur at time before onset of flooding (OOF) and detected from sensor 4 and sensor 7 when $\mathrm{JG}=1.64 \mathrm{~m} / \mathrm{s} /$. At same JG, onset of flooding was detected first time by sensor 4 in region II. Further, flooding was occurred continually and makes instability in fill layer [9].

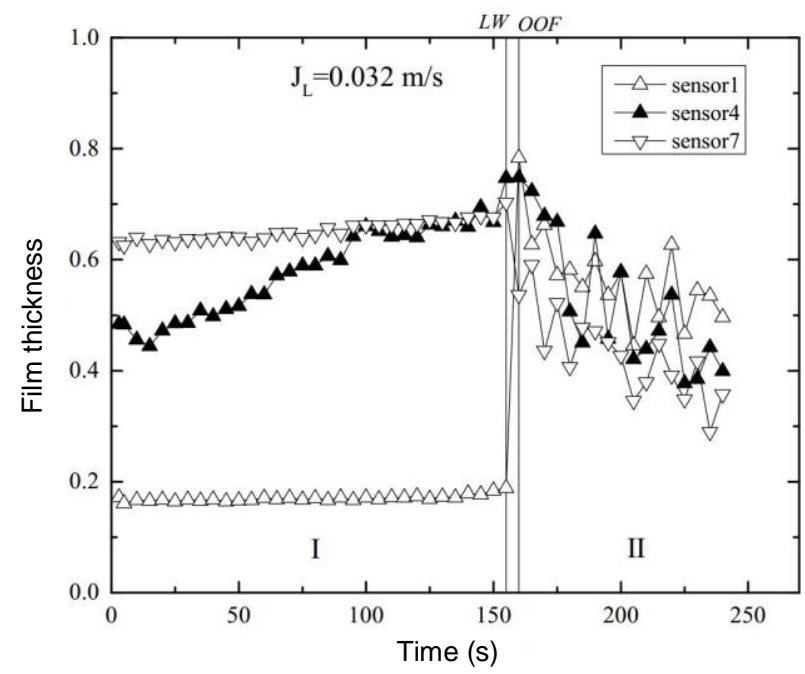

Figure 3.4 Normalization response of film thickness to time for $J_{L}=0.032 \mathrm{~m} / \mathrm{s}$.

\subsection{Measurement of Film Thickness for $\mathrm{JL}=\mathbf{0 . 0 6 5} \mathrm{m} / \mathrm{s}$}

On $\mathrm{JL}=0.065 \mathrm{~m} / \mathrm{s}$, the changes of flow pattern and onset of flooding could be observed by sensor 4, 6, and 7 as shown by Figure 3.5 and Figure 3.6.

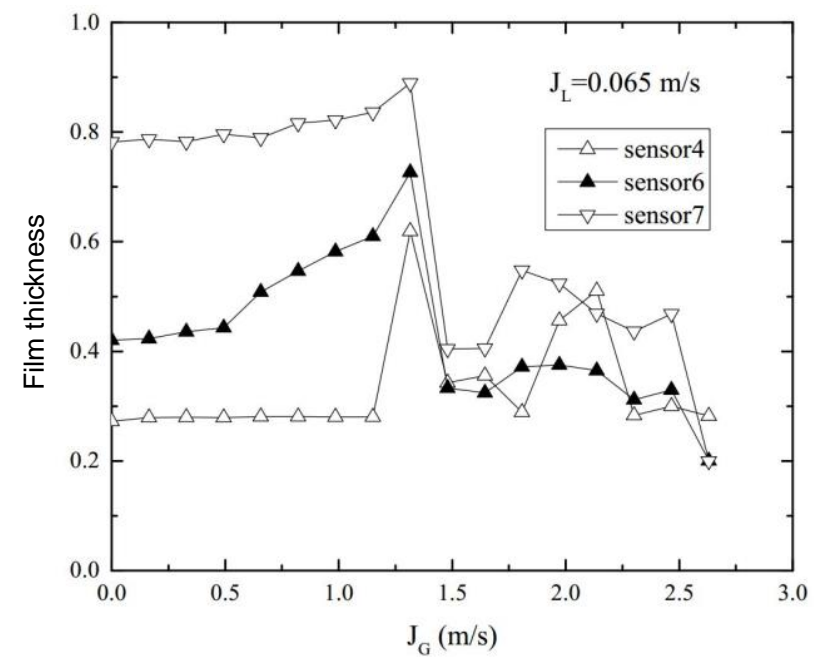

Figure 3.5 Normalization response of film thickness to change of JG for $J L=0.065 \mathrm{~m} / \mathrm{s}$.

Figure 9 show the superficial velocity of water was higher, the position onset of flooding occurrence was detected for lower JG. As for the results of previous measurement on film thickness, onset of flooding was marked by sudden changes in film thickness. The increase of film thickness abruptly was detected on sensor 4 when $J G=$ $1.31 \mathrm{~m} / \mathrm{s}$. While on sensor 7 , onset of flooding was marked by decreasing of film 
thickness abruptly. Hydraulic jump was detected on sensor 6 and marked by gradual increasing of film thickness until right before flooding. It was observed that liquid film was accumulated in sensor 7 so that very thick layer was detected. Accumulated liquid film was occurred by hydraulic jump which located far from elbow.

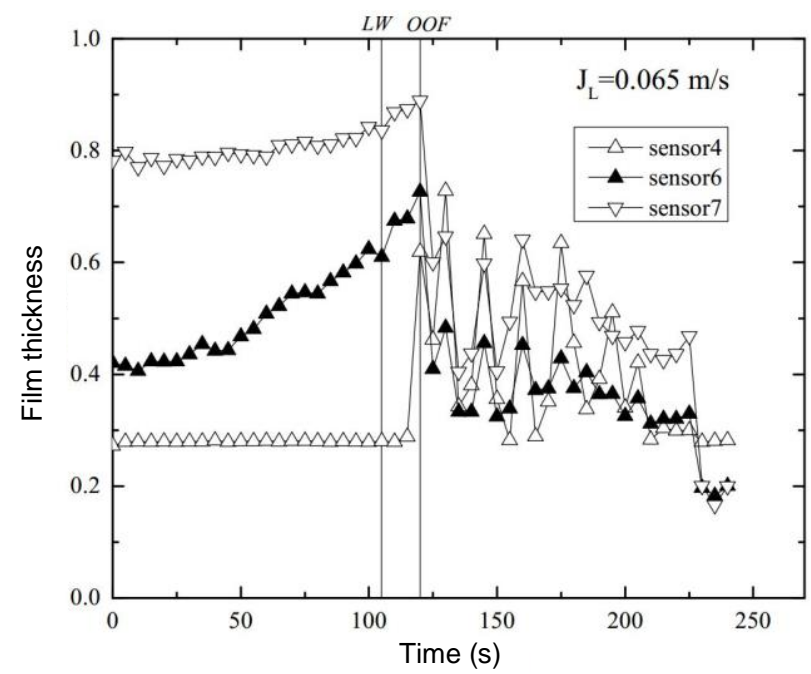

Figure 3.6 Normalization Response of Film Thickness to time for $J_{L}=0.065 \mathrm{~m} / \mathrm{s}$.

Based on Figure 3.6, Large Wavy (LW) flow was generated on $105^{\text {th }}$ second and was detected first time on sensor 6 . On $J G=1.15 \mathrm{~m} / \mathrm{s}$, onset of flooding (OOF) was detected on sensor 4 on the range of 15 second after LW. After onset of flooding, film instability of flow occurred. For a short of time, it can be observed that film layer of flow was going zero on $240^{\text {th }}$ second. The phenomenon was occurred at same time when variation of $\mathrm{JL}$ was lower. It can be observed that higher $\mathrm{JL}$, then position of onset of flooding become away from elbow and also the position of onset of flooding also. Another result also show that higher JL made time of occurrence of flow pattern changes, position of onset flooding, and hydraulic jump also become faster. This was in accordance with previous research [10], [11].

\section{CONCLUSION}

Based on the measurement of film thickness which employed conductance of parallel-wire method, it can be concluded that the methods was successful in detecting the characteristic of film thickness of counter current flow of water-air phase. Observed flow pattern was stratified flow and large wavy. Method of parallel-wire also able to detect position of hydraulic jump and onset of flooding based on position of installed sensors. From the measurement, variation of $\mathrm{JL}$ has influence on time occurrence of flow pattern, hydraulic jump, and onset of flooding. Position of hydraulic jump and onset of flooding also become farther from elbow as $\mathrm{JL}$ increase. The time of the occurrence of onset of flooding become faster when JL higher.

\section{REFERENCES}

[1] Deendarlianto, Vallée, C., Lucas, D., Beyer, M., Pietruske, H., Carl, H., 2008, Experimental Study on The Air/water Counter-current Flow Limitation in A Model of the Hot Leg of A Pressurized Water Reactor, Nuclear Engineering and Design, Vol. 238 (12), pp.3389-3402.

[2] Bankoff S.G., Lee S.C., 1983, A Critical Review of The Flooding Literature. Multiphase Science and Technology Vol. 2, Springer-Verlag Berlin Heidelberg, Page 98. 
[3] Brown, R.C., Andreussi, P. and Zanelli, S. (1978), The Use of Wire Probes for the Measurement of Liquid Thickness in Annular Gas-Liquid Flows, Can. J Chern. Eng. 56: 754-757.

[4] Koskie, J.E., Mudawar, I., Tiederman, W.G. (1989), Parallel Wire Probes for Measurements of Thick Liquid Films, Int. J Multiphase Flow 15:521-530.

[5] Andriyanto S., Anam B., Indarto, Deendarlianto, Experimental Investigation of Liquid Holdup in Horizontal Two Phase Annular Flow Using Constant Electric Current Method (CECM), Seminar Nasional ke-8 Tahun 2013: Rekayasa Teknologi Industri dan Informasi, STTNAS.

[6] Badarudin A., Indarto, Deendarlianto, W. S. Manurung, Karakterisasi Tebal Cairan pada Aliran Dua Fase Udara-Air Berlawanan Arah dalam Pipa Kompleks pada Bagian Horizontal Menggunakan Metode Parallel-wire, Proceeding National Symposium on Thermofluids VIII, Yogyakarta, 10 November 2016.

[7] Badarudin A., Indarto, Deendarlianto, Hermawan, Saka A., M. Fikri H. S., Wicaksono A., Observasi Karakteristik CCFL pada Ppa Kompleks, Seminar Nasional ke-9: Rekayasa Teknologi Industri dan Informasi, Sekolah Tinggi Teknologi Nasional, Yogyakarta, 2016, pp. 371-375.

[8] Badarudin A., Arman M., Interpretasi Hasil Pengukuran Tebal Cairan pada Aliran Dua Fase Udara-Air Berlawanan Arah Menggunakan Metode Parallel-Wire dalam Pipa Kompleks, Prosiding Seminar Nasional XI "Rekayasa Teknologi Industri dan Informasi, Sekolah Tinggi Teknologi Nasional, Yogyakarta, 2016.

[9] S. Al Issa, R. Macian, 2011, A Review of CCFL Phenomenon, Annals of Nuclear Energy 38 pp. 1795-1819.

[10] Deendarlianto, Ousaka, A., Kariyasaki, A., Fukano, T., 2005. Investigation of Liquid Film Behavior at The Onset of Flooding During Adiabatic Counter-Current Air-Water Two Phase Flow in An Inclined Pipe, Nuclear Engineering and Design, Vol. 235, pp.2281-2294.

[11] Wongwises, S., 1996, Two-Phase Countercurrent Flow in A Model of A Pressurized Water Reactor Hot Leg, Nuclear Engineering and Design Vol. 166, pp.121-133. 